\title{
A Comparative Analysis of the Factors Effecting the Employee Motivation and Employee Performance in Pakistan
}

\author{
Muhammad Rizwan \\ Lecturer, Department of Management Sciences \\ The Islamia University of Bahawalpur, Pakistan \\ E-mail: rizwan.arshad@iub.edu.pk
}

Mahum Tariq

Department of Management Sciences, The Islamia University of Bahawalpur, Pakistan

E-mail: mahum_abbasi@hotmail.com

Rabab Hassan

Department of Management Sciences, The Islamia University of Bahawalpur, Pakistan

E-mail: Rabi_hassan11@yahoo.com

Amna Sultan

Department of Management Sciences, The Islamia University of Bahawalpur, Pakistan

E-mail: Lonerider504@yahoo.com

Doi:10.5296/ ijhrs.v4i3.5873 URL: http://dx.doi.org/10.5296/ ijhrs.v4i3.5873

\begin{abstract}
Employee motivation is considered as a force that drives the employees toward attaining specified goal and objectives of the organization. Now days it is one of the sizzling issue in organizations since every wants to make best use of their financial and human resources. Our Purpose of this study is basically to identify that what kind of factors influence employ motivation in Pakistan and up to which extent motivation affects the employee performance. Two preceding factors influence the employ motivation. By using self-administered questionnaires we collected data from our 150 respondents. For regression analysis we entered all that that data into SPSS and do analysis also. Results of our study show significant
\end{abstract}


relationship of employ motion and employ performance. Our study is a vital source for the national and international HR personnel's to collect information how different factors effect employee motivation and performance.

Keywords: Employee motivation, employee performance, intrinsic rewards and employee perceived training effectiveness.

\section{Introduction}

"The only way to get people to like working hard is to motivate them. Today, people must understand why they're working hard. Every individual in an organization is motivated by something different. When talking in term of employee motivation it can be simply defined as "Employee motivation is a reflection of the level of energy, commitment, and creativity that a company's workers bring to their jobs." The job of a manager in the workplace is to get things done through employees. To do this the manager should be able to motivate employees. But that's easier said than done! Motivation practice and theory are difficult subjects, touching on several disciplines.

In spite of enormous research, basic as well as applied, the subject of motivation is not clearly understood and more often than not poorly practiced. To understand motivation one must understand human nature itself. And there lies the problem! Human nature can be very simple, yet very complex too. An understanding and appreciation of this is a prerequisite to effective employee motivation in the workplace and therefore effective management and leadership.

Employee motivation is very important for organizations as every concern requires physical, financial and human resources to accomplish the goals. It is through motivation that the human resources can be utilized by making full use of it. This can be done by building willingness in employees to work. This will help the enterprise in securing best possible utilization of resources. It results into increase in productivity, reducing cost of operations, and improving overall efficiency.

Goals can be achieved if co-ordination and co-operation takes place simultaneously which can be effectively done through motivation. Stability of workforce is very important from the point of view of reputation and goodwill of a concern. The employees can remain loyal to the enterprise only when they have a feeling of participation in the management. The skills and efficiency of employees will always be of advantage to employees as well as employees. This will lead to a good public image in the market which will attract competent and qualified people into a concern.

Organizations in this dynamic globalized world are continuously trying to develop and motivate their employees to help achieve enhanced performance with various Human Resource applications and practices. Reward management system is the highly used practice for the enterprises to achieve the desired goals (Güngör, 2011). According to Barber and Bertz (2000), Reward management system helps the organizations to attract, capture, retain and motivate employees with high potential and in return get high levels of performance. 
Reward management system consists of both extrinsic and intrinsic rewards; where former involves financial rewards (salary, bonus etc) and the later includes non-financial rewards like recognition, security, title, promotion,, appreciation, praise, decision making involvement, flexible working hours, workplace comfort ability, feedback, work design, social rights etc (Yang, 2008).

According to a study conducted by Grant (2008), motivation imposes employee outcomes for instance performance and productivity. He also established that motivated employees are more oriented towards autonomy and are more self-driven in contrast to less motivated employees. Further, motivated employees are highly engaged and involved in their work and jobs and are more willing to take responsibilities (Kuvaas\&Dysvik, 2009).

Following are the variables which directly affects the employee motivation,

Training is the formal process by which a person acquires knowledge, skills, and competencies. Motivation is the direction and intensity of one's effort, or the psychological feature that arouses an organism to action toward a desired goal. Organizations that use training practices, directly or indirectly effect employee motivation as well as commitment to the organization (Meyer \& Allen, 1991). According to Rowden and Conine (2005), the purpose of training is to enhance the satisfaction of employees towards their jobs and satisfied employees contend their customers with enhanced performance. Employees who commit to learn are more satisfied with their jobs and ultimately show more positive performance than others (Tsai et al, 2007). In line with Tsai et al (2007), Harrison (2000) established that learning that is prompted by training positively effects employee performance and is an essential element for the achievement of organizational goals (Harrison, 2000).

An intrinsic reward is an intangible award of recognition or a sense of achievement motivation, in any endeavor when one feels in the Maslows hierarchy as attainment in conscious satisfaction. It is the knowledge that one did something right, or one made some body's day better. Hence reward management systems (specifically intrinsic rewards) positively motivate employees and ultimately affect their individual and organizational performance. Pool and Pool (2007) and Lok and Crawford (2004) claim commitment of workers with motivation and job satisfaction with motivation has a predictable link. Similarly perceived training effectiveness is highly correlated with the job satisfaction of employee, supporting the conclusions of Tsai et al in (2007).

\section{Literature Review}

\section{Employee Motivation}

Motivation is basically meant to enable behavioral change. It is a drive that enables an individual to act in the direction of a specific goal. According to the study of Grant (2008) held on employee motivation; motivation imposed such outcomes as productivity, performance and persistence (Grant, 2008). According to the studies of (Ryan and Deci, 2000; Thomas, 2002, as cited in Grant, 2008); motivated employees are more oriented towards autonomy and freedom and are more self driven as compared to less motivated employees 
resulting in availing developmental opportunities more responsibly. Similarly employee engagement with their work and jobs is more if they are motivated as compared to less motivated employees (Guay et al., 2000; Vansteenkiste et al., 2007).

Organizational behavior is a subject that is rich with the literature on motivation including various models and theories related to motivation. It is heavily focused on the development and growth of employes. According to Maslow, Alderfer, McClelland, Hackman and Hertzberg; the most powerful motivator for individuals is growth that maximizes the potential of employees. It is found that an undeniable link exists between employee motivation and their satisfaction with the jobs and also to organizational commitment (Basset-Jones) and (Lloyd,) 2005 ;( Chen et al)., 2004; (Lok and Crawford,) 2004; (Pool and Pool),(2007).

According to the results of the study conducted on the relationship among motivation and job satisfaction of employees by Sirota et al. (2005) having 135,000 respondents from different groupings and countries, organizations implementing various motivation programs involving three constructs as camaraderie, equity and achievement are two more effective things than organizations which are having as many 'passionate' employee (of total 45\%).

H1: Employee motivation has a significant and positive relationship with employee performance.

\section{Employee Performance}

Performance of the employee is considered as what an employee does and what he doesn't do. Employee performance entails quality and quantity of output, presence at work, accommodative and supportive nature and timeliness of output. According to the results of the study conducted by Yang (2008) on individual performance showed that performance of the individuals cannot be verified. Similarly he asserts that organizations can use direct bonuses and rewards based on individual performance if employee performance is noticeable (Yang, 2008; Rizwan et al., 2013).

In line with Yang (2008), Bishop (1987) investigated employee performance and revealed that acknowledgment and recognition and reward of performance of employees directs the discrimination between employee productivity.Moral and productivity of employees is highly influenced by the effectiveness of performance of an organization and its rewardmanagement system (Yazıcl, 2008; Rizwan et al., 2013).

The relationship between employee performance and reward system is best explained by the 'path-goal model'. According to this model, if an employee observes high productivity as a path escorting to the accomplishment of his one or more personal goals, he will be inclined to produce high. In contrast, if he observes low productivity as a path to the accomplishment of his personal goals, he will produce low. 


\section{Intrinsic Reward}

An interest in the task itself driven by individual internally rather than external forces and reliance on external rewards refers to intrinsic motivation. Organizations continuously need something to keep their workers working including salary alone or bonuses etc., but motivation is the very important factor to keep the workers engage and involve in their work so that their quality and quantity of work and productivity does not deteriorate.(Williams, 2004),

Intrinsic reward basically deals with the satisfaction of employee to his jobs emerging out of the pleasure of working that he experiences in a good organization that rewards him for his job. Rewards are very meaningful to employees whether they are extrinsic or intrinsic. Intrinsic reward emerges in a person after the accomplishment of certain task or work (joy, satisfaction, pride etc.); while extrinsic motivation comes from outside sources or forces as salary, money or grades etc.(Scott and Bruce, 1994),.

A person who is intrinsically motivated will work with a math problem because it is enjoyable or he will find a solution to a problem because it is challenging and will give him a feeling of pleasure after solving it. Inboth the cases no external reward isimportant to the person such as payment or prize(Roberts, 1991 and Rothwell, 1992).It doesn't mean that extrinsic reward is not important to a person but it means that it is not only sufficient to keep the person motivated(Eisenberger and Cameron,1996; Janssen, 2000; Mumford, 2000)

H2: Intrinsic reward has a significant and positive relationship with employee performance.

H3: Intrinsic reward has a significant and positive relationship with employee motivation.

\section{Employee Perceived Training Effectiveness}

In order to achieve the goals of the organization efficiently and effectively, management of the organizations require training of its members. Training is very useful for the employees in various ways as: it keeps them up to date with the fast changing trends and environment of the dynamic globalized world; helps anxiety and frustration reduction caused from work overload or demand of work; helps improve talents that how efficiently it can be handled etc(Chen et al., 2004). Workers who feel they are les competent for the task to fulfill will leave the field or if they become constant than they can easily achieve the level of productivity.(Kanelopoulos and Akrivos, (2006).

The biggest gap among what an individual possesses and what he requires, the greater is the dissatisfaction with the job and the higher are the turnover rates. Even though there does not exist a direct connection in literature between job satisfaction and training yet Rowden (2002) and Rowden and Conine (2005), suggest that training can be an effective device to enhance satisfaction from the job. Similarly Rowden and Conine (2005)privilege that workers whose training is effective can better satisfy the needs and demands of their consumers. In line with 


\section{Macrothink}

International Journal of Human Resource Studies ISSN 2162-3058 2014, Vol. 4, No. 3

them Tsai-e-al. (2007), stated that the workers who show their commitment to training and learning possess an enhanced level of job satisfaction that positively affects their performance.

Training practices directly or indirectly affect the motivation of employees and heir commitment to the organizations (Meyer and Allen, 1991).Training defined "as to enhance the individuals job performance determinants intervention is designed" $\{C h i a b u r u\}$ and \{Tekleab, \}(2005, p. 29).

H4: Employee perceived training effectiveness has a significant and positive relationship with employee motivation.

\section{Research Model}

Figure: Structural Model Results

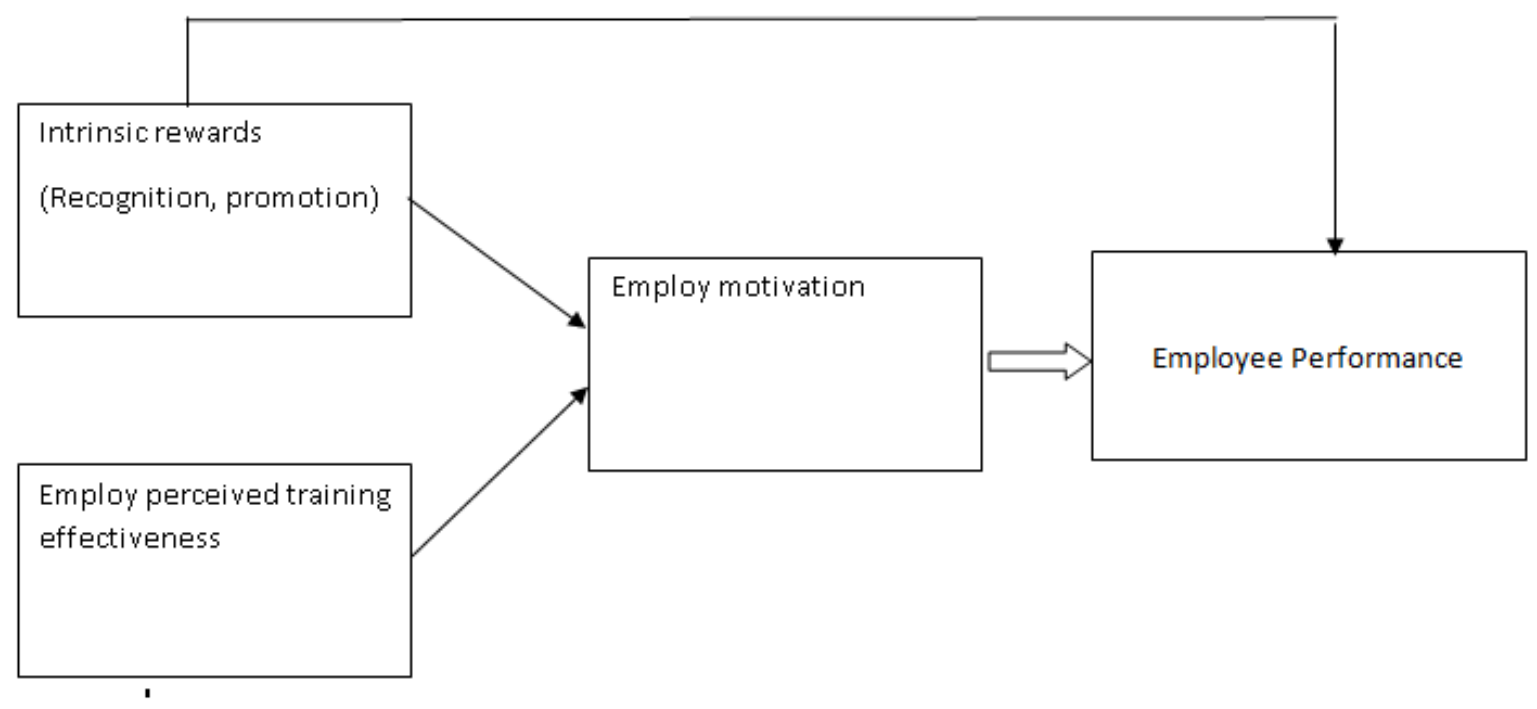

\section{Research Methodology:}

The present research is descriptive research which means describing, elaborating or explaining some particular phenomenon or a situation. According to Creswell (1994) descriptive research deals with the description of a present situation rather than making judgments or interpreting something (Creswell, 1994). The current research deals with verifying the proposed hypotheses reflecting the present situation. 


\section{Macrothink}

\subsection{Sample Data:}

The population for the present study is the teaching faulty of government schools in Bahawalpur, Pakistan.160 respondents were asked to participate in the filling of self-administered questionnaire. The proposed study uses convenience sampling which is a technique of non-probability sampling. Convenience sampling deals with obtaining and collecting relevant information from the sample of the study or the unit in the study that are easily and conveniently available (Zikmund, 1997).

\subsection{Instruments and Measures:}

There are two major purposes of the current study address of the survey instruments: First one is the relationship of different variables in the adoption of employee motivation should be analyzed. Second, to collect information about the respondents of different characteristics it could be used to understand the different categories variations. The instruments survey contains two sections. Section 1 includes different personae and demographic variables. This section will obtain the respondent's information about gender, age, income and education.

Latent variables are included in section 2 that are important in the current study. These variables includes employee motivation, employee performance, intrinsic reward and employee perceived training effectiveness. This section of study is developed based on the already used questionnaires and past literature. From the previous literature and published studies the scale of study was adopted. The first variable of the study was employee motivation having six items taken from Chang and Chen (2008). The next variable is employee performance having three items that was taken from the study of Chen (2010). The next variable was intrinsic reward having five items refers to Patterson and Spreng (1997). The next variable employee perceived training effectiveness having four items refers to Armstrong and Kotler (2009).

Table 1: $\quad$ Scales of the Study

\begin{tabular}{|c|c|c|c|}
\hline No & Variable & Items & Reference \\
\hline 1. & $\begin{array}{l}\text { Employee } \\
\text { motivation }\end{array}$ & $\begin{array}{l}\text { 1. I feel a sense of personal satisfaction } \\
\text { when I do this job well. } \\
\text { 2. My opinion of myself goes down when I } \\
\text { do the job badly. } \\
\text { 3. I take pride in doing my job as well as I } \\
\text { can. } \\
\text { 4. I feel unhappy when my work is not up to } \\
\text { my usual standard. } \\
\text { 5. I like to look back at a day's work with a } \\
\text { sense of a job well done. }\end{array}$ & $\begin{array}{l}\text { (The McKinsey } \\
\text { Quarterly, 2006) }\end{array}$ \\
\hline
\end{tabular}




\begin{tabular}{|c|c|c|c|}
\hline & & $\begin{array}{l}\text { 6. I try to think if ways of doing my job } \\
\text { effectively. }\end{array}$ & \\
\hline 2. & $\begin{array}{l}\text { Employee } \\
\text { performance }\end{array}$ & $\begin{array}{l}\text { 1. My performance is better than that of my } \\
\text { colleagues with similar qualifications. } \\
\text { 2. I am satisfied with my performance } \\
\text { because its mostly good. } \\
\text { 3. My performance is better than that of } \\
\text { bankers with similar qualifications in } \\
\text { other banks. }\end{array}$ & Bishop (1987) \\
\hline 3. & $\begin{array}{l}\text { Intrinsic } \\
\text { reward }\end{array}$ & $\begin{array}{l}\text { 1. The organization allows them to grow as a } \\
\text { person, improve self confidence overcome } \\
\text { the weakness, mature foster their self } \\
\text { esteem. } \\
\text { 2. Their activity in the organization } \\
\text { matches/it's their ethics and moral values. } \\
\text { 3. The organization environment, in which } \\
\text { their activity is embedded is } \\
\text { cooperative,and foster mutual respect, and } \\
\text { there is friendship and interpersonal trust } \\
\text { among employees. } \\
\text { 4. The organization is fair regarding internal } \\
\text { management procedures/methods. } \\
\text { 5. They have sense of belonging regarding } \\
\text { the organization themselves a part of the } \\
\text { organization are loyal/faithful to the } \\
\text { organization. }\end{array}$ & Frey (1997) \\
\hline 4. & $\begin{array}{l}\text { Employee } \\
\text { Perceived } \\
\text { training } \\
\text { effectiveness }\end{array}$ & $\begin{array}{l}\text { 1. My company provides me the opportunity } \\
\text { to improve my skills. } \\
\text { 2. There is lot of chance to learn new things } \\
\text { in this company. } \\
\text { 3. My company frequently arranges training } \\
\text { programs for the employees. } \\
\text { 4. Doing job in this company will benefit to } \\
\text { me. }\end{array}$ & $\begin{array}{l}\text { (Chiaburu and } \\
\text { Tekleab, 2005) }\end{array}$ \\
\hline
\end{tabular}




\section{Macrothink}

\subsection{Procedure}

The questionnaire was distributed among 160 respondents in Bahawalpur City of Pakistan. These respondents are selected based on the criteria above mentioned. Before giving the questionnaire, the purpose of the study and questions were explained to the respondents so they can easily fill the questionnaire with relevant responses. A total of 160 questionnaires were selected. After collecting, the completed questionnaires were coded and entered into SPSS sheet for further analysis.

\subsection{Reliability Analysis}

Overall Cronbach's alpha of Employee Motivation questionnaire items were 0.621. This shows that all the 18 items were reliable and valid to measure the opinions of employees towards Employee Motivation.

Table 2: Reliability of Measurement Instrument

\begin{tabular}{|l|l|l|}
\hline Scales & Items & Crounbach Alpha \\
\hline Employee Motivation & 6 & 0.759 \\
\hline Employee Performance & 3 & 0.483 \\
\hline Intrinsic Reward & 5 & 0.636 \\
\hline $\begin{array}{l}\text { Employee perceived training } \\
\text { effectiveness }\end{array}$ & 4 & 0.619 \\
\hline
\end{tabular}

\section{Results and Analysis.}

\subsection{Profile of the Respondents}

Personal and demographic information of the respondents is presented in the following table.

Table 3: profile of the respondents

\begin{tabular}{|l|l|l|l|}
\hline & Category & Frequency & Percentage \\
\hline Variable & & & \\
\hline Gender & Male & 73 & 46 \\
\hline
\end{tabular}




\begin{tabular}{|c|c|c|c|}
\hline & Female & 87 & 54 \\
\hline Age & $\begin{array}{l}\text { 15-20 years } \\
20-25 \text { years } \\
25-30 \text { years } \\
\text { 30-35 years } \\
\text { 35-40 years } \\
\text { Above } 40 \text { years }\end{array}$ & $\begin{array}{l}20 \\
87 \\
40 \\
8 \\
2 \\
3\end{array}$ & $\begin{array}{l}54 \\
25 \\
5 \\
1 \\
2\end{array}$ \\
\hline Income & $\begin{array}{l}\text { Below } 15000 \\
15000-25000 \\
25000-35000 \\
35000-45000 \\
45000-55000 \\
\text { Above } 55000\end{array}$ & $\begin{array}{l}50 \\
40 \\
35 \\
12 \\
5 \\
18\end{array}$ & $\begin{array}{l}31 \\
25 \\
22 \\
8 \\
3 \\
11\end{array}$ \\
\hline Education & $\begin{array}{l}\text { Matriculation } \\
\text { Inter } \\
\text { Bachelor } \\
\text { Master } \\
\text { MS/M.Phill } \\
\text { PHD }\end{array}$ & $\begin{array}{l}10 \\
67 \\
70 \\
12 \\
1\end{array}$ & $\begin{array}{l}6 \\
42 \\
44 \\
8\end{array}$ \\
\hline
\end{tabular}

\subsection{Hypothesis Testing}

This section of the study finally tests the model after satisfying the requirements of reliability and validity. The casual relationships of the independent variable were measured on dependent variables.

\subsubsection{Intrinsic reward and Employee motivation}

According to the results of the study. The variable intrinsic reward has a significant positive relationship with Employee motivation. Specifically this variable has a significant positive relationship with $(B e t a=0.330)$ and $(\mathrm{p}<0.01)$. That means the intrinsic reward more than $50 \%$ to Employee motivation. Results of the current study validate the H1. 


\section{Al Macrothink \\ International Journal of Human Resource Studies \\ ISSN 2162-3058 \\ 2014, Vol. 4, No. 3}

\subsubsection{Employee perceived training effectiveness and Employee motivation}

The regression results of the study confirm the negative relationship between Employee training and motivation with $($ Beta $=-0.003)$ and $(\mathrm{p}<0.01)$. According to these results, Employee perceived training effectiveness contributes more than $3 \%$ to Employee motivation. This result of study validates $\mathrm{H} 2$.

\subsubsection{Intrinsic reward and Employee performance}

Regression analysis of the employee motivation model shows that there is a significant positive relationship with $($ Beta $=0.197)$ and $(\mathrm{p}<0.01)$. The results suggest that intrinsic reward almost 19\% more than Employee performance. The result of the study support H3.

\subsubsection{Employee motivation and Employee performance}

The regression results of the study confirm the significant positive relationship between Employee motivation and Employee performance with $($ Beta=0.353) and $(p<0.01)$. According to these results, Employee motivation is 35\% more than Employee performance. The result of the study support H4.

Table 4: Regression Results

\begin{tabular}{|c|c|c|c|c|c|c|}
\hline Hypothesi & Model Variables & Estimate & S.E & C.R & $\mathbf{P}$ & Results \\
\hline H1 & EM & 0.330 & 0.086 & 3.917 & 0.000 & supported \\
\hline $\mathrm{H} 2$ & ${ }_{\mathrm{EM}}^{\mathrm{EMPE}}$ & -0.003 & 0.092 & -0.030 & 0.976 & $\begin{array}{l}\text { Not } \\
\text { supported }\end{array}$ \\
\hline $\mathrm{H} 3$ & EP & 0.197 & 0.041 & 2.621 & 0.010 & supported \\
\hline $\mathrm{H} 4$ & EM & 0.353 & 0.040 & 4.703 & 0.000 & supported \\
\hline
\end{tabular}




\section{Figure: Structural Model Results}

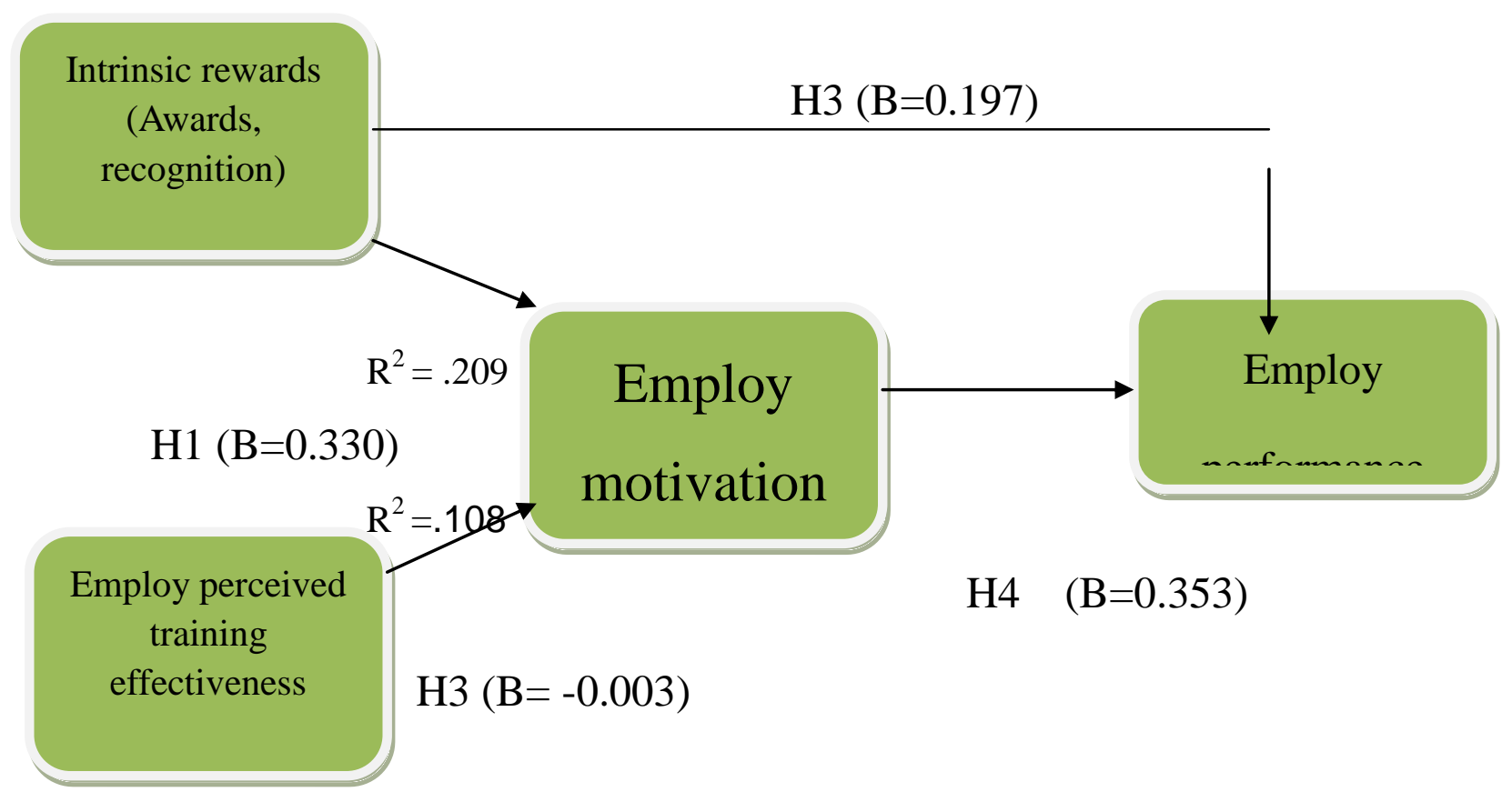

The purpose of the current study is to investigate the major factors that effects employ motivation and the employ performance in the public sector of Pakistan. To fulfill the purpose a research the factor that suited the conditions of the country were selected and applied over the public sector. . To find out the extent to which each of them affects the employ motivation in public sector two employ motivation factors that are intrinsic reward and employ perceived training effectiveness. Apart from the effect of these factors over brand loyalty, this study is also aimed to highlight their effects on each other, for this purpose the effect of intrinsic rewards over the employ performance is also taken under consideration. Pakistan is a country ideal for the motivation of employees. Individuals working in B2B (business to business) segments affirmed that they were motivated by the autonomy and freedom they were given to work, by the responsibility they were given and by the position and tasks they were provided by the management. This affirms Herzberg theory in connection with the studies of Mausner and Snyder man that when people are intrinsically satisfied with their work, it leads to better performance and enhanced satisfaction with their jobs (Herzberg et al., 2003).

According to some of the respondents, art; design or architecture could be feasible motivational forces but respondents did not clearly state these forces to have a direct impact on motivation. Though respondents generally suggested these three constructs to have an impact on motivation as they improve the physical environment in which the employees work. The reason given was that if the physical environment for working is improved, it enhances the well being, moods and encouragement of employees which ultimately impacts motivation. Some of the respondents did not affirm to this statement as they were least interested in the 
physical environment.

Over all we found the support of all the factors (intrinsic rewards, employ motivation) except the employ perceived training effectiveness. As shown by the statistical analysis results intrinsic rewards are the most important factor in the development of the employ motivation. The effect of intrinsic reward over was found to be significant to $(B=0.330)$ and the effect of intrinsic reward over the employ performance is also significant with $(B=0.197)$ hence supporting $\mathrm{H} 1$ and $\mathrm{H} 3$. The intrinsic rewards increase the employ motivation in the way that intrinsic rewards are proven have greatly increase the motivation by many studies, intrinsic rewards give a scene of satisfaction to the employs and a satisfied employ is always motivated and tends to perform better.

The effect of employ motivation over the employ performance is also significant with $(\mathrm{B}=0.353)$ prove the $\mathrm{H} 4$. The motivated has always been the motivating force towards the employ performance so a motivated employ tends to perform well.

But the effect of employ perceived training effectiveness o employ motivation is insignificant with $(B=-0.003)$. That is because the study sample is having the majority of respondent from government schools teachers and they are hardly given training for their job that why it has no effect over their motivation level so the hypothesis was not supported.

The relevant variables to this study are employee motivation, employee performance, intrinsic reward and Employee perceived training effectiveness. To capture the dimensions of these variables, a set of multi-item instruments that draw on previous empirical research was used. The study took the relevant information from the teaching faculty of government schools. According to their responses, they were provided with the training courses but this training was not implemented by them in their routine teaching as they considered it to be ineffective. They were not satisfied with the training provided to them and this affected their motivation to teach.

\section{Limitation and future research}

This research has shown how relating to theory-building approach to linking aesthetics in organizations, culture of organization and brand building capacity provides an emergent theory and a conceptual model, which suggests how elements of an organization's physical environment may influence the organizational culture, dimensions, and thus, the possible consequences on for service provision among employees. Longitudinal design must be taken to overcome this limitation. In contrast, construct validity of the career motivation should be examined when career work is needed and check the relationship of employee behavior and it attitude towards some extent. Survey is conducted in the period of economic recession. In order to findings, the assess of generality it is suggested to repeat the research in a stable economy situation.

To identify and control possible effects that were not considered in this study, more variables should be studied in future, such as demographic characteristics, personal characteristics, abilities, and needs for goal achievement in examining employee motivation. To enhance the validity in the behavioral criterion, variables should be added to expectancy theory. Extra 
studies might investigate more demographically different groups of employees to determine whether diverse motivation strategies should be used. Motivation is complex, so continuous in-depth study will help the managers of the hotel industry motivate employees effectively. The two main limitations are focus on a subset elements and the limited scope of states-of-mind and behaviors measured.

\section{References}

${ }^{1}$ Barber, A.E., Dunham, R. and Formisano, R.A. (1992), “The impact of flexible benefits onemployee satisfaction: a field study", Personnel Psychology, Vol. 45, pp. 55-75.

Alderfer, C. (1972), Existence, Relatedness and Growth: Human Needs in Organizational Settings,Free Press, New York, NY.

Basset-Jones, N. and Lloyd, G.F. (2005), "Does Herzberg's motivation theory have stayingpower?", The Journal of Management Development, Vol. 24, pp. 929-43.

Chen, Y., Lou, H., 2002. Toward an understanding of the behavioral intention to use a groupware application. Journal of End User Computing 14, 1-16

Chiaburu, D.S. and Tekleab, A.G. (2005), "Individual and contextual influences on multiple dimensions of training effectiveness", Journal of European Industrial Training, Vol. 29

No. 8, pp. 604-26.

Rizwan, M., Shahid, M., Shafiq, H., Tabassum, S., Bari, R. \& Umer, J. (2013) Impact of Psychological Factors on Employee Turnover Intentions, International Journal of Research in Commerce, Economics and Management, 3(3), 63-69

Deci, E.L. and Ryan, R.M. (2000), "The 'what' and 'why' of goal pursuits: human needs and theself-determination of behaviour", Pshychological Inquiry, Vol. 11 No. 4, pp. 227-68Lovelock, C.H. (1996), Services Marketing, Prentice-Hall,

Greenwich, CT. Ryan, R.M. and Deci, E.L. (2000), "Intrinsic and extrinsic motivations: classic definitions and new directions", Contemporary Educational Psychology, Vol. 25 No. 1, pp. 54-67

Rizwan, M., Shahzad, N., Sheikh, Q., Batool, S., Riaz, M. \& Saddique, S. (2013) Variables that Have an Impact on Employee Satisfaction And Turnover Intention, International Journal of Research in Commerce, Economics and Management, 3(3), 131-138

Harrison, R. (2000), Employee Development, Beekman Publishing, Silver Lakes, Pretoria.Pool, S. and Pool, B. (2007), “A management development model”, Journal of Management Development, Vol. 26 No. 4, pp. 353-69.

Kanelopoulos, C. and Akrivos, C. (2006), "Career development in Greek management", 


\section{Macrothink \\ International Journal of Human Resource Studies \\ ISSN 2162-3058 2014, Vol. 4, No. 3}

Spoudai,Vol. 56 No. 1, pp. 79-106.

Kuvaas, B. and Dysvik, A. (2009), "Perceived $\square$ nvestment in Employee Development, $\square$ ntrinsic Motivation and Work Performance”, Human Resource Management Journal, 19(3), pp. 217-236.

Meyer, J. and Allen, N. (1991), “A three component conceptualization of organizationalcommitment”, Human Resource Management Review, Vol. 1 No. 1, pp. 61-90.

Rowden, R.W. and Conine, C.T. Jr (2005), "The impact of workplace learning and job satisfactionin small US commercial banks”, Journal of workplace Learning, Vol. 17 No. 4, pp. $215-30$

Tsai, P., Yen, C.Y., Huang, L. and Huang, I. (2007), “A study on motivating employee's learningcommitment in the post-downsizing era: job satisfaction perspective", Journal of World Business, Vol. 42 No 2pp 157-69

Vansteenkiste, M., Lens, W. and Deci, E.L. (2006), "Intrinsic versus extrinsic goal contents in self-determination theory: another look at the quality of academic motivation", Educational Psychologist, Vol. 41 No. 1, pp. 19-31.

Yang, H. (2008), "Efficiency Wages and Subjective Performance Pay”, Economic Inquiry, 46(2), pp. 179-196.

Yazıc1, N. K., "The Effect Of Reward System Applications On Employee Performance In Service Sector", (2008), Marmara University, Institute of Social Sciences, Master Thesis.. 